\title{
Do Nova Scotians really want industry?
}

G. W. I. CREIGHTON, former deputy minister of Lands and Forests for Nova Scotio, gives his views in this article from the Halifax Chronicle-Herald on a controversy regarding the establishment of a woodlot marketing board in Nova Scotia.

We Nova Scotians present a strange paradox. We continually complain that we need more industry but just as soon as we get a reasonably good industry established, we immediately attack it, and it would almost seem that we strive to make it leave our province.

A good example of this is presented by our pulp and paper companies. They are denounced because they are foreign owned, they are large, they lease crown lands, they pollute our air and water, they destroy our forests and rob our woodlot owners. With one exception they are foreign owned, but Nova Scotians in general refuse to invest in pulp and paper and we have invited and urged foreign companies to come into our province.

Back in the early fifties Nova Scotia's steel industry was ailing, the coal mines were dying and the provincial government was trying desperately to attract new industry, particularly to Eastern Nova Scotia. Our forests appeared to offer some hope and numerous pulp companies in and out of Canada were approached. Representatives from a number of companies visited our province, but one after another lost interest first because we lacked the huge solid blocks of crown forest found in other provinces and secondly because all our timberland lies inside municipal boundaries and so may be subject to municipal taxation.

Eventually two companies did show some interest and after the defeat of the Hicks government, Mr. Hicks turned over to Mr. Stanfield his files containing correspondence with these two companies. The Stanfield government pursued negotiations with vigor and as a result Nova Scotia Pulp ${ }^{1}$ located at the Strait of Canso and Scott in Pictou County.

Both companies are foreign owned and both are subsidiaries of large corporations. In the case of Nova Scotia Pulp this is perhaps fortunate since it has lost over three million dollars every year since 1962 and without the financial support of a strong parent it would have been forced to close down long ago. In an attempt to become a profitable venture Nova Scotia Pulp has enlarged its chemical mill and built a ground wood and a newsprint mill.

In order to induce these companies to locate in Nova Scotia it was necessary for the provincial government to lease them substantial areas of crown land, but in the case of Scott, which already had sizeable holdings of private land, the lease was confined to Eastern Halifax County.

Under the terms of the two pulpwood leases, the companies do not have exclusive use of the lands and every Nova Scotian is guaranteed the right to hunt, fish and trap on the properties. The companies must prepare management plans and may only cut when these plans are approved and as directed by the Minister of Lands and Forests. Further the com-

${ }^{1}$ Now called Nova Scotia Forest Industries Ltd. panies pay a fixed charge for each cord of wood cut on crown lands and the rate is set on a sliding scale which increases substantially from time to time. In addition monies are paid to the province and municipalities in lieu of taxes.

The pulp and paper mills do pollute our air and water but steps are being undertaken to correct the situation which give promise of being successful. The pulp companies are condemned for excessive clear cutting with heavy equipment. Some of this criticism may be justified but not entirely.

Not too long ago most woods operations in Nova Scotia were for saw logs that were cut with axes and crosscut saws, and the logs were moved from stump to portable steam mills with horses. Trees cut for saw logs were the largest and best while smaller trees, sick, deformed and unmerchantable species were left. While this so-called selective logging left some forest cover which guaranteed a future crop, that crop got poorer and poorer... Today operators, saw logs as well as pulpwood, have been faced with two alternatives, mechanize or die. Where a woodlot owner keeps a horse, he can still log cheaper with old dobbin than any other way, and in this case selective logging properly carried out is probably the best method.

While the companies have little alternative than to clear cut on a large scale, unfortunately they have cut some young stands that should have been left and they could improve their public image if they would tidy up along roadside and lake shores.

Undoubtedly legislation is necessary, but unfortunately legislation regulating cutting on private woodland has been a political football. The so-called Bill 151 was introduced by a Conservative government in the early 1930's but was attacked by a Liberal opposition on the grounds that it infringed on the rights of the private land owner, and it never got beyond a second reading. By the middle forties public clamor was so strong that a Liberal government passed The Small Tree Act which followed closely the wording of Bill 151. The Small Tree Act restricted the cutting of spruce, pine and hemlock less than 10 inches in diameter at a point one foot from the ground. While leaving much to be desired, the act was enforced and prevented the cutting of many young stands.

This act in turn was attacked by a Conservative opposition and in time was repealed by a Conservative government and replaced with the Forest Improvement Act, which has been proclaimed only in part and never enforced. Since both major parties have had a try at forest legislation relating to private woodland, it would be nice if all parties would work together and devise some sensible legislation that can be enforced for the good of all Nova Scotians.

In this modern era it seems that for a pulp company to thrive it must expand, and in this province with our limited area any marked expansion will 
have to be accompanied by more intensive forest management to grow more wood in a shorter period.

Actually, the potential is here to grow twice as much wood as we are presently using and the major companies have recently embarked on a program of thinning and planting to speed up future growth on their holdings. At the present time, the companies own and lease about 34 per cent of our woodland and the other 66 per cent must supply saw logs for about 350 saw mills and any pulpwood needed in excess of what can be produced from company limits.

During the past few years and especially in recent months, there have been many complaints about pulpwood prices received by the private landowner, and requests have been made to have the price and sale of pulpwood regulated by a Pulpwood Marketing Board.

The most prolonged demand comes from the Nova Scotia Woodlot Owners Association. This association has been formed largely through the efforts of the Extension Division of St. Francis Xavier University which for the past several years received an annual grant of $\$ 40,000$ of federal money paid through the provincial Department of Lands and Forests.

A woodlot owners' association can and should be a very useful organization, and the Lunenburg County Christmas Tree Producers' Association, an affiliate of the Woodlot Owners Association, is doing an excellent job learning and teaching improved methods of growing and marketing better trees in order to obtain for its members a larger share of the price paid by the final consumer.

The main body of the Woodlot Owners Association seems to have confined its efforts largely to condemning the pulp companies and demanding the establishment of a Pulpwood Marketing Board, under the opinion that this will result in higher pulpwood prices, an opinion which might or might not be true.

Ten years ago, before the two chemical pulp mills went into production, a woodlot owner had several markets for his product. He could sell logs to the saw mills, there was a limited market for high grade spruce and fir pulpwood; to the then-operating one newsprint mill and two groundwood mills; and the export market purchased still higher quality spruce and fir peeled pulpwood. There was a dwindling demand for mine timber, together with a limited market for fuelwood, poles and piling.

When the chemical pulp mills commenced operations, all softwood species, pine, hemlock and larch, in addition to spruce and fir, became saleable along with some hardwood and the new companies accepted wood of much lower quality with much more stain and rot than could or would be acceptable by a groundwood or newsprint mill. The new mills also purchased wood in eight-foot lengths.

With the present market for all species and for low quality wood, it is often possible to harvest two and even three times as much volume from a given acre than was possible before. Since the other markets for wood still exists, many smart operators sell their best logs to the saw mills for a much better price and then sell to the pulp mills wood that formerly lay on the ground as waste.

If it was certain that a pulpwood marketing board would help the private landowner and the overall economy of the province, there would be little grounds to oppose it, other than the fact that many Nova Scotians are individualists and don't like to be pushed around and would resent having a deduction from each cord of wood sold, to pay for a board they don't want.

If a marketing board is set up, it will follow that grades must be established to determine price, and the price presently being paid at roadside for all species, low-quality, low-density cord is little out of line with the price paid elsewhere for high quality spruce and fir delivered to the mill.

At the present time, wood located over 100 miles from the mills is being sold and the companies pay transportation costs. Any marked upward revision in price by a board could well mean that wood any great distance from a mill could not be sold, and with present budworm damage, the companies could justify increased cutting on their own lands which would result in less wood purchased from private land owners.

The sawmills which are owned by Nova Scotians have to compete with the pulp mills for logs from private land and in order to compete successfully they have to pay a higher price. Some sawmills obtain all or part of their logs from pulp company limits, and many more would like a share in some of the high quality company wood being manufactured into pulp. The saw mills, in turn, deliver to the pulp companies each year the equivalent of 120,000 cords of chips from sawmill waste. The lumber operators of the province do not favor a board and as an alternative have suggested a commission.

As a woodlot owner who produces a few saw logs, some pulpwood and fuelwood, who was a long-time government employee and who as a young man worked for, and was fired by, a big pulp company, I am biased and prejudiced.

I do not believe in giving arbitrary authority to boards or commissions. I believe that such authority properly rests with a duly-elected minister of the Crown. I suggest that the Forest Improvement Act be amended to cover the needs of this province. The Minister of Lands and Forests has a competent staff at his disposal and after he is provided with the necessary authority and legislation see that he enforces it and makes it work.

In conclusion, I would point out that our pulp and paper companies are not all good or all bad, but they do manufacture a renewable resource into end products worth some $\$ 70$ million a year and with recently-increased capacity this should reach $\$ 100$ million by 1973 . They also give gainful employment to thousands of Nova Scotians. Without our pulp mills there would be fewer jobs and more empty stomachs in Nova Scotia. 